\section{Modern Sanitation}

\section{In an Iranian Village}

\author{
By Frederick F. Aldridge, M.S.S.E., \\ Eugene Baird, B.P.H., and \\ Vigen Gevorkian, B.S.C.E.
}

$\mathrm{T}$ HROUGH the cooperative efforts of villagers, the Iranian Ministry of Health, and the United States Foreign Operations Administration (formerly Technical Cooperation Administration), the Iranian village of Ali Shah Avaz, located about 30 miles southwest of Teheran, today has a safe water supply, several hundred sanitary privies, and a sanitary public bath. These facilities have replaced an open ditch water supply and unprotected wells, uncovered shallow pit latrines, and an immertion "pool" public bath.

Mr. Aldridge, a commissioned officer of the Public Health Service now on assignment with the Foreign Operations Administration Mission to India as assistant chief sanitary engineer, was chief sanitary engineer for the Technical Cooperation Administration (now Foreign Operations Administration) Mission to Iran from 1951 to 1953. Mr. Baird, also a commissioned officer of the Public Health Service, is with the Mission to Iran as sanitarian for the Teheran region. Mr. Gevorkian, a graduate student in sanitary engineering at the University of Minnesota, was the Iranian Ministry of Health's sanitary engineer for the Teheran region from 1951 to 1953.

Mr. Aldridge was formerly director of the division of sanitation, and Mr. Baird was district sanitarian, Seattle-King County Department of Public Health, Seattle, Wash. Mr. Aldridge has also served as sanitary engineer for refugee camps in the Middle East, and as chief sanitary engineer of the health division, United Nations Relief and Rehabilitation Administration.
The sanitation program in this village is a part of the public health program of the United States Foreign Operations Administration being carried out in Iran. In the summer of 1951, an area named Shahriar, composed of about 200 villages bordering and just southwest of Teheran, was designated by the Iranian Government as an experimental area in rural improvement. Many letters had come from these villages describing their living conditions and requesting assistance from the Foreign Operations Administration in improving them. United States and Iranian sanitary engineering personnel investigated the problems in these villages and found that the insanitary conditions existed in approximately the same degree in all of them. The village of Ali Shah Avaz was chosen as the starting point for an environmental sanitation program in this area because it is the largest village in the area, with a population of about 400 farmers and small landowners, and because it is the center of the greatest activity for the Iranian governmental agencies, including the Ministry of Health.

\section{Sanitation Problems}

The mayor of Ali Shah Avaz called a general meeting of the villagers to discuss the sanitation problems with the United States and Iranian sanitary engineers. The major problems were an inadequate supply of safe drinking water, insanitary privies, and insanitary public bathing facilities.

The principal supply of water for drinking, as well as for bathing and washing clothes, was surplus irrigation water which was carried from a mountain underground source through a ghanat-a series of shafts and interconnecting underground tunnels- to the upper edge of the village and from there through the village in an open ditch called a jube. All along its route through the village, animals wandered through the water at random, women washed clothes and utensils in it, and children waded and played in it. By improvising temporary dams and side ditches, drinking water was conducted into and 


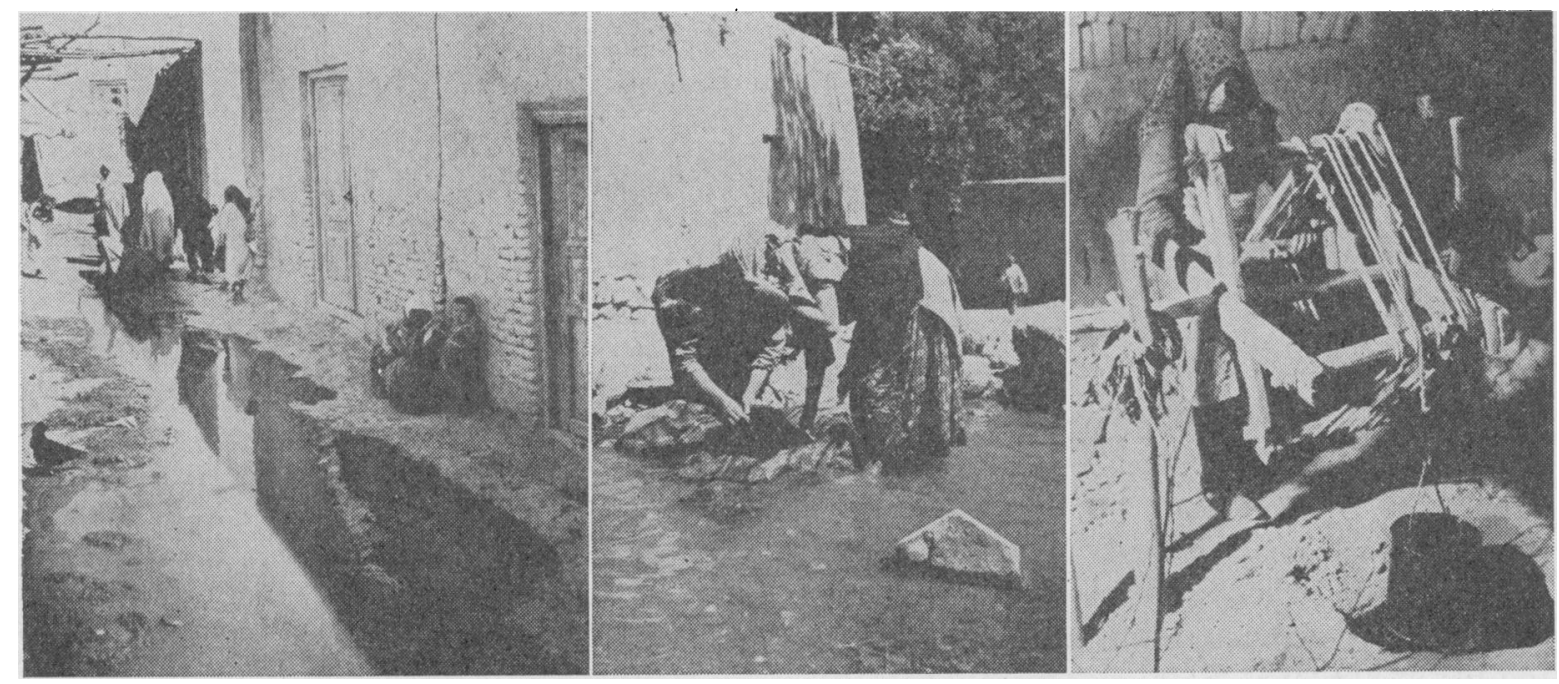

An open ditch (left and center) was the principal source of water in Ali Shah Avaz for drinking, bathing, and washing before the sanitation program was begun in the fall of 1951 . Another source was hand-dug, uncased, open wells (right), which were sometimes located within a few feet of the family privy.

stored in underground reservoirs, called umbars, filled by gravity flow and located along the path of the open ditch.

Hand-dug, uncased, open wells were another source of drinking water. The water was obtained by means of a rope, bucket, or goatskin bag, and a hand-operated windlass. These wells were often located within just a few feet of the family privy.

Waterborne diseases, such as typhoid and the dysenteries, were constantly in near epidemic form in the village, and they were a major factor in the high infant mortality rate. It has been conservatively estimated that the infant mortality in the average Iranian village is approximately 50 percent in the first year, and that 50 percent of the survivors die before they reach the age of 6 years.

In each compound, which houses from 1 to 3 families, a shallow pit privy was the only means of excreta disposal. The privies were open pits, 3 to 4 feet wide, ranging in depth from 2 to 5 feet depending on the ground water level of the area. Surface drainage and seepage from these pits could easily reach the wells. Flies were observed to breed in the pits and moved freely from them to the food in the houses and shops.

Two underground structures, each with a large pool in the center, were the public baths for the village. The water was heated from underneath the pool by brush and wood fires. Additional water was provided once a month, but the water was never changed. Through the common use of this type of bath, communicable diseases, such as skin infections and even trachoma, could be easily spread.

\section{Sanitation}

The first step in getting the sanitation program under way in Ali Shah Avaz was the formation of a community cooperative. This organization, composed of about eight members and a director, represented the village in planning and carrying out the program. The members and director were elected by popular vote on a written ballot.

On October 19, 1951, the drilling of a deep well was begun, and on December 1, 1951, it was completed. The well is located in the center of the village on land donated to the village cooperative by an individual landowner. It is 230 feet deep and provides 25,000 gallons of water a day. The total cost was $\$ 10,000$, which includes the cost of drilling and the provision and installation of a turbine pump and a 52horsepower diesel engine.

A pumphouse and a 3,000-gallon storage reservoir were built, for which the Foreign Op- 


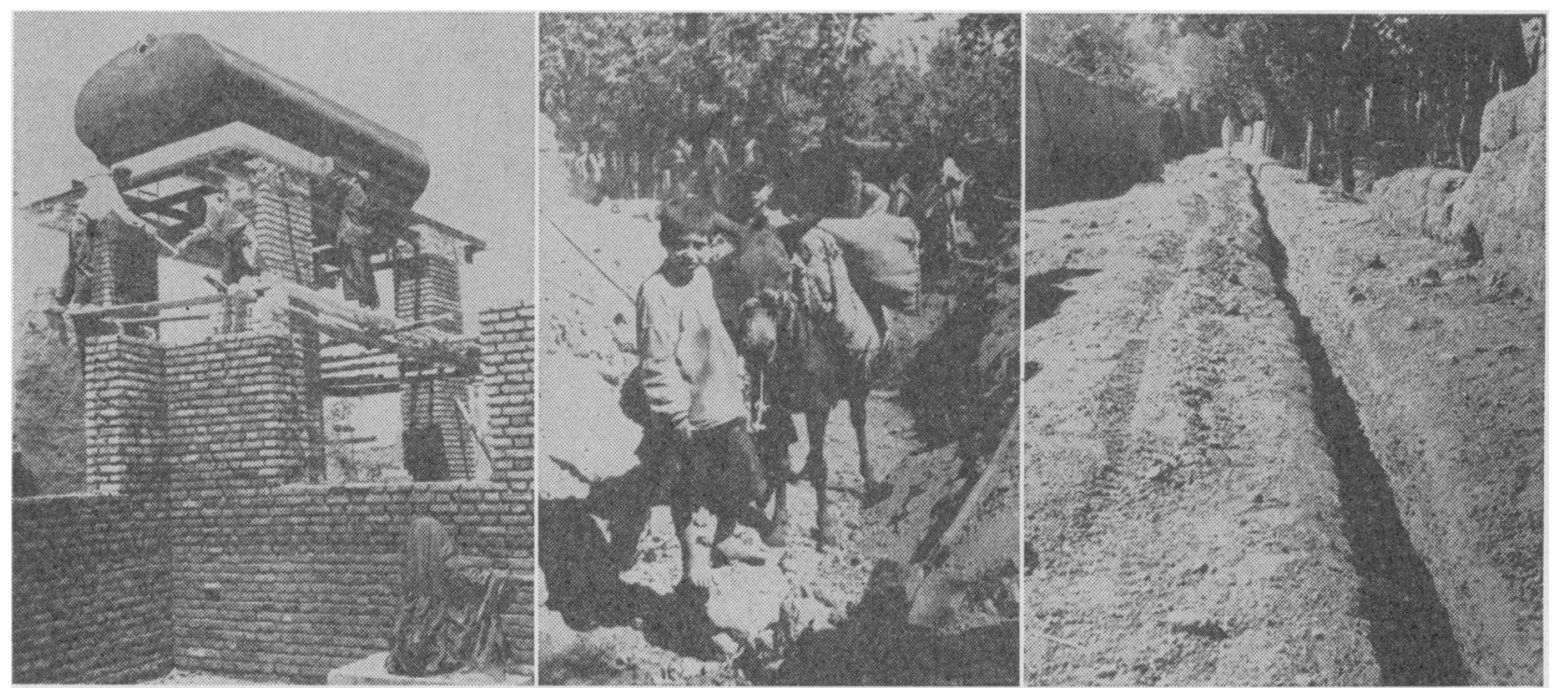

Construction of a pumphouse and storage reservoir (left), with material furnished by the Foreign Operations Administration and labor provided by the village, was a part of the water supply project. Pipeline trenches for a 3,500 foot water distribution system were dug by the villagers (center and right).

erations Administration provided the material and the community cooperative provided the labor. After completion of the reservoir and pumphouse, the villagers dug trenches for a water distribution system consisting of 3,500 feet of $21 / 2$-inch galvanized pipe. Water taps were installed approximately 150 feet apart. Two village men were trained to operate and maintain the pump and engine, and after one month's operation under the supervision of the Iranian sanitary engineers, the complete installation was turned over to the cooperative.

For the first time in the history of this village, safe and adequate drinking water is available to the people. In addition, large quantities of water from this well are used for irrigation. The sale of the irrigation water covers the expense of operating the well, including the salaries of the operators and the cost of the fuel and upkeep.

In the privy construction program which began soon after the completion of the water supply system, Iranian sanitarian-aides played an important part. Sanitarian-aides are young men with a sixth- to ninth-grade education who have been trained, in the field and in the classroom, in basic sanitation by the United States and Iranian sanitary engineers. In Ali Shah Avaz, their job was to explain to the people why privies should be constructed in a sanitary manner and how to construct them. Several hundred sanitary privy slabs, designed and provided by the Foreign Operations Administration, were installed by the villagers under supervision of the sanitarian-aides according to specifications drawn up by the sanitary engineers.

With the completion of the water supply system and the construction of sanitary privies, the people for the first time began to understand the true meaning of sanitation. Upon their own initiative, they decided to build a new sanitary public bath. The director of the village cooperative asked the United States and Iranian sanitary engineers for assistance, and several joint meetings were held in the village. It was learned that the cooperative had already purchased the necessary land for a bathhouse site and had raised about half the funds required for the construction of a 14-shower brick bathhouse. The plans, the essential piping and equipment, and supervision of construction were provided by Iranian and American sanitary engineers. The villagers did all the construction work, furnishing both skilled and unskilled labor, and provided the material necessary for the building. The bathhouse was completed and put into operation in May of 1953. 


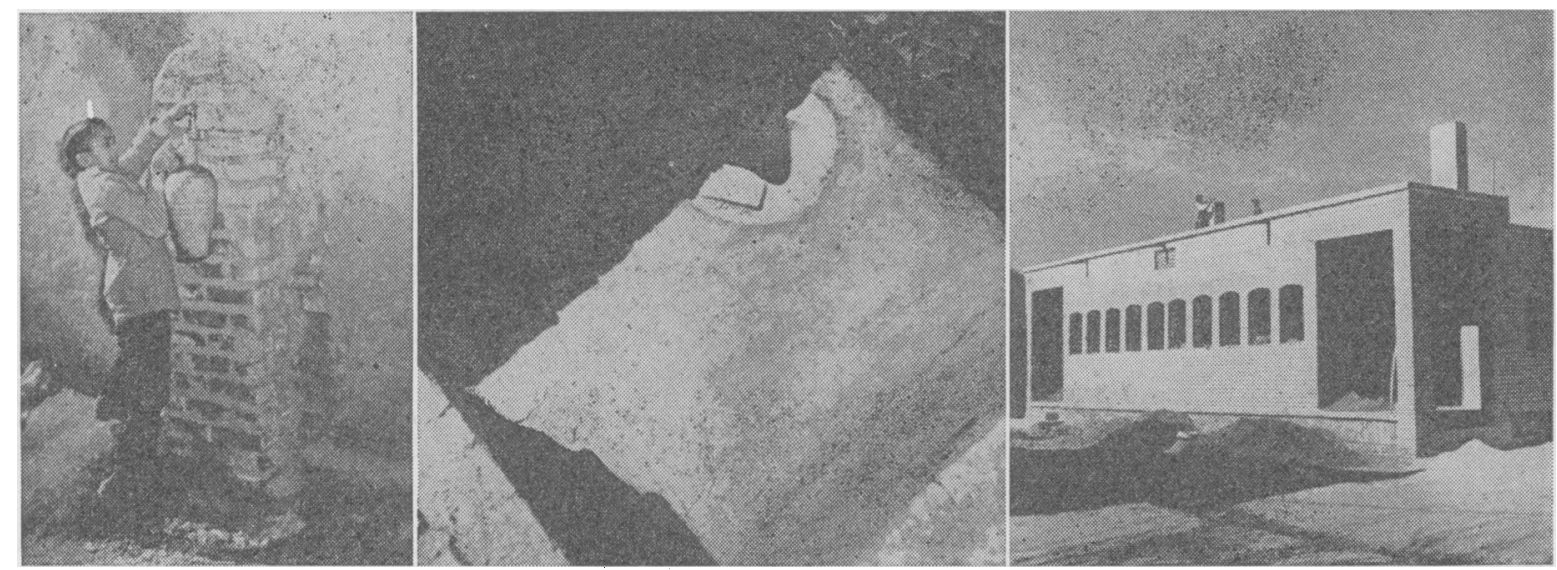

Water taps (left) were installed about 150 feet apart along the principal streets of the village. New sanitary privies were dug and concrete slabs installed (center). With the aid of Iranian and American sanitary engineers, the villagers built a brick bathhouse containing 14 showers (right).

\section{Malaria Conirol}

Along with these improvements in sanitation, a DDT-spraying program to control malaria was undertaken. Malaria has been one of the most prevalent and destructive diseases, in Iran from both the health and economic points of view. According to Iranian estimates, 3 to 4 million cases occurred annually among a total population of 17 million. The malaria rate in the average village located in a malarious area ranged from 50 to 100 percent. During the harvest season, crops often rotted in the fields because the farmers were too ill to harvest them. True, they felt better during the winter months, if they survived, but it was then too lato to harvest the crop, and a good portion of the year's income and food supply was lost.

In Ali Shah Avaz, the United States technicians discussed with the villagers the importance of malaria control. Ten villagers volunteered to spray the houses in the village. They were given detailed instruction in mixing and spraying DDT and performed the work under the supervision of two Iranian sanitarian-aides. The incidence of malaria has already declined, according to survey studies of the World
Health Organization malaria advisory team in Iran. Since spraying will be continued in subsequent years, it can be expected that malaria will eventually be eradicated.

\section{Summary}

With the provision of safe drinking water, sanitary bathing facilities, and sanitary privies, the major sanitation prablems of Ali Shah Avaz are a thing of the past. Such allied problems as elimination of fly breeding, food sanitation, home sanitation, and school sanitation are still to be solved, but work has already begun on them. The villagers are sincerely desirous of improving the health conditions of their village, and they realize that through modern sanitation many of their prevalent diseases can be greatly reduced, some of them even eliminated. Through the village cooperative, they have learned how to work together for the benefit of the whole community, and with the aid of trained Iranian sanitarian-aides, they are able to cope with their problems. Through modern sanitation, these people are raising their standards of living and are finding a new way of life.

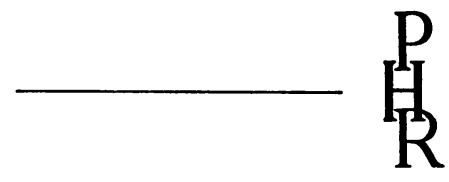

